\title{
Pengaruh Kualitas Pelayananan terhadap Loyalitas Penumpang Maskapai Penerbangan Batik Air
}

\author{
https://doi.org/10.25008/caraka.v2i2.63 \\ Grace Natalie Valencia \& A.G Sudibyo \\ Sekolah Tinggi IImu Komunikasi (STIKOM) InterStudi - Jakarta
}

\begin{abstract}
This study aims to obtain empirical results regarding the effect of service quality on passenger loyalty at Batik Air. The research method used is quantitative with the type of verification research. Data collection techniques using a questionnaire. The population used is Batik Air passengers for the 2019 period, which is 10,989,896 people. The sampling technique used non-probability sampling with the type of technique, namely purposive sampling. The sample in this study as many as 100 respondents passengers Batik Air. The data analysis technique used in this research is simple linear regression analysis. The results show that the service quality of Batik Air affects passenger loyalty. Service quality can provide an impetus for passengers to establish a strong long-term bond with Batik Air or referred to as loyalty.

Keywords: public relations; service quality; passenger loyalty
\end{abstract}

\begin{abstract}
ABSTRAK
Penelitian ini bertujuan untuk memperoleh hasil empiris mengenai pengaruh kualitas pelayanan terhadap loyalitas penumpang Batik Air. Metode penelitian yang digunakan adalah kuantitatif dengan jenis penelitian verifikatif. Teknik pengumpulan data menggunakan kuesioner. Populasi yang digunakan adalah penumpang Batik Air periode tahun 2019 yaitu sebanyak 10.989 .896 orang. Teknik sampling menggunakan non probability sampling dengan jenis teknik purposive sampling. Sampel dalam penelitian ini sebanyak 100 orang responden penumpang Batik Air. Teknik analisis data yang digunakan adalah analisis regresi linear sederhana. Hasil penelitian menunjukan, kualitas pelayanan Batik Air berpengaruh terhadap loyalitas penumpang. Kualitas pelayanan dapat memberikan suatu dorongan kepada penumpang untuk menjalin ikatan jangka panjang yang kuat dengan Batik Air atau disebut sebagai loyalitas.
\end{abstract}

Kata kunci: hubungan masyarakat; kualitas pelayanan; loyalitas penumpang

Grace Natalie Valencia's email: grcnatalie@gmail.com

Para penulis menyatakan tidak mempunyai konflik kepentingan dalam penelitian dan penerbitan publikasi ini.

Copyright (C) 2021 (Grace Natalie Valencia).

Licensed under the Creative Commons Attribution-NonCommercial-ShareAlike 4.0 (CC BY-SA 4.0)Available at http://caraka.web.id

Submitted: 5 Agustus 2021, Revised: 20 Oktober 2021, Accepted: 24 Desember 2021 


\section{PENDAHULUAN}

Persaingan perusahaan penerbangan di Indonesia semakin ketat, karena banyaknya perusahaan penerbangan mencari, menarik, serta mempertahankan penumpang dengan tujuan memuaskan para pengguna jasanya. Dunia maskapai memiliki dua kategori pelayanan jasa, yakni full service carrier (FSC) dan low cost carrier (LCC). Salah satu perusahaan maskapai di Indonesia yang menggunakan pelayanan jasa full service carrier adalah Batik Air. Maskapai penerbangan di bawah Lion Air Group itu, sampai saat ini kondisinya stabil dalam bersaing dengan maskapai penerbangan lainnya, terutama dalam peforma pelayanan.

Beberapa pelayanan penuh yang disediakan Batik Air untuk kelas ekonomi adalah proses check-in ditemani oleh duta Batik Air untuk membantu proses check-in, bebas biaya bagasi $20 \mathrm{~kg}$, fasilitas in-flight entertainment seperti film, lagu, games, hingga kursi pesawat yang nyaman. Batik Air didukung pramugari serta pramugara yang lebih senior dibandingkan Lion Air. Hal ini dapat menjadi nilai tambah bagi penumpang, karena dianggap dapat memberikan suasana yang lebih nyaman.

Sebagai perusahaan yang menjual jasa, bentuk pelayanan Batik Air dinilai secara langsung oleh calon penumpang. Pelayanan yang baik dicerminkan melalui pelayanan yang diberikan. Jika pelayanan yang diberikan di luar keinginan calon penumpang, maka citra Batik Air menjadi buruk. Sedangkan bila pelayanan yang diberikan sudah sangat baik dan sesuai keinginan calon penumpang, maka secara tidak langsung akan timbul citra yang baik bagi Batik Air.

Pelayanan yang baik belum tentu berkualitas. Pelayanan disebut berkualitas jika faktorfaktor seperti bukti fisik, daya tanggap, keandalan, jaminan, serta empati terpenuhi. Kualitas pelayanan dapat memberikan dorongan kepada penumpang untuk menjalin ikatan jangka Panjang yang kuat dengan Batik Air atau disebut sebagai loyalitas. Penumpang yang loyal merupakan aset penting dalam setiap perusahaan.

Loyalitas penumpang mutlak diperlukan Batik Air untuk bersaing dengan industri maskapai penerbangan lain. Untuk dapat membangun loyalitas penumpang, dibutuhkan usaha-usaha dari Batik Air dan memberi mutu layanan terbaik, sehingga tercipta suatu anggapan mutu pelayanan yang kokoh di benak penumpang.

Penumpang yang loyal dapat membuka kesempatan untuk memperoleh penumpang baru. Mempertahankan penumpang yang telah ada akan lebih menguntungkan bila dibanding dengan pergantian penumpang karena membutuhkan biaya lima kali lipat untuk menarik penumpang baru. Intinya, pelayanan berkualitas diharapkan dapat menghasilkan dasar yang baik untuk terciptanya loyalitas penumpang berupa pembelian ulang kembali tiket penerbangan.

Berdasarkan latar belakang di atas, maka identifikasi masalah yang dikemukakan dalam penelitian ini adalah: (1) bagaimana kualitas pelayanan Batik Air?; (2) Bagaimana loyalitas penumpang Batik Air kelas ekonomi?; (3) Apakah terdapat pengaruh antara kualitas pelayanan Batik Air terhadap loyalitas penumpang kelas ekonomi?; (4) Seberapa besar pengaruh antara kualitas pelayanan Batik Air terhadap loyalitas penumpang kelas ekonomi?

Ada pun tujuan penelitian ini adalah: (1) Untuk imengukur ikualitas pelayanan Batik Air; (2) Untuk mengetahui/mengukur loyalitas penumpang Batik Air kelas ekonomi; (3) Untuk mengetahui apakah terdapat pengaruh antara kualitas pelayanan Batik Air terhadap loyalitas penumpang kelas ekonomi; (4) Untuk mengukur seberapa besar pengaruh antara kualitas pelayanan Batik Air terhadap loyalitas penumpang kelas ekonomi.

\section{KERANGKA TEORI}

Public relations adalah fungsi manajemen serta seluruh wujud komunikasi terencana baik internal maupun eksternal, antara suatu organisasi dengan seluruh khalayaknya, dalam 
rangka memperhitungkan sikap-sikap publik, mengenali kebijakan-kebijakan dan prosedurprosedur dari individu ataupun organisasi dengan dasar kepentingan publik serta melakukan rencana kerja untuk menggapai tujuan-tujuan khusus yang didasarkan pada saling memelihara saling pengertian, dukungan, serta kerjasama satu perushaan dengan publiknya (Soemirat, 2010); (Yadin, 2004).

Fungsi utama dari public relations memiliki inti, meliputi: (1) Sebagai komunikator ataupun perantara antar organisasi yang diwakili publiknya; (2) Menjalin ikatan, berupaya menjalankan suatu ikatan yang positif dan saling menguntungkan dengan publiknya; (3) Peran back up management, sebagai suatu pendukung pada fungsi manajemen organisasi ataupun perusahaan; (4) Membentuk suatu citra perusahaan, fungsi public relations berupaya menciptakan citra dan reputasi bagi organisasinya (Ruslan, 2005).

Tujuan public relations sebagai terbentuknya serta terpelihara rasa saling pengertian (aspek kognisi), membentuk dan menjaga rasa saling percaya (aspek afeksi) dan menciptakan serta memelihara kerjasama, aspek psikomotoris (Frida, 2002).

Public relations dibedakan berdasarkan kegiatannya: (1) Internal public relations, kegiatan internal relations ditujukan kepada kebijaksanaan perusahaan yang sedang dijalankan mencakup suatu evaluasi terhadap tingkah laku dan opini publik terhadap perusahaan; (2) Eksternal public relations, kegiatan eksternal relations untuk mendapatkan suatu dukungan dari publik maupun mengubah pendapat publik sesuai yang diinginkan oleh komunikator dengan metode menyelenggarakan komunikasi efisien yang memiliki suatu sifat yang informatif dan persuasif (Danandjaja, 2011).

\section{Kualitas Pelayanan}

Pelayanan diartikan sebagai "kegiatan yang dilakukan dengan didasarkan pada faktor materi dengan prosedur, sistem serta metode tertentu oleh seseorang atau sekelompok orang dalam rangka memenuhi kepentingan orang lain sesuai haknya" (Moenir, 2010).

Pada hakikatnya, layanan merupakan sebuah proses dalam sebuah rangkaian kegiatan, pelayanan dilakukan secara terus menerus dan berkesinambungan, mencakup semua kehidupan orang dalam masyarakat. Kualitas pelayanan diartikan sebagai "upaya yang memerlukan ketepatan dalam penyampaiannya guna mengimbangi harapan pelanggan agar keinginan serta kebutuhan pelanggan terpenuhi" (Tjiptono, 2007).

Kualitas layanan yang baik serta sesuai dengan kebutuhan pengguna jasa publik yakni faktor yang menentukan dalam menjaga kelancaran organisasi perusahaan. Upaya untuk menciptakan kepuasan pengguna jasa publik (customer satisfaction) sangatlah penting yang dalam penelitian ini adalah kemampuan Batik Air untuk memenuhi keinginan untuk menciptakan loyalitas pelanggan.

\section{Dimensi Kualitas Pelayanan}

Terdapat lima dimensi kualitas pelayanan menurut Parasuraman yaitu: Bukti Fisik (Tangibles). Kemampuan perusahaan penyedia jasa dalam memberikan eksistensinya berupa pelayanan secara fisik sebagai bukti nyata kepada publik eksternalnya seperti fasilitas fisik (gedung), perlengkapan serta peralatan yang digunakan (teknologi), dan tampilan pegawainya.

Keandalan (Reliability). Keahlian perusahaan saat menyediakan layanan dengan akurat dan terpercaya sesuai apa yang dijanjikan perusahaan. Hal-hal yang dapat dilakukan dalam sebuah pelayanan pelayanan harus sesuai dengan apa yang pelanggan harapkan seperti sikap yang simpatik, pelayanan yang sama untuk semua pelanggan tanpa adanya kesalahan, ketepatan waktu, dan juga tingkat akurasi pelayanan yang tinggi. 
Daya Tanggap (Responsiveness). Kemampuan internal perusahaaan terutama para karyawan untuk membantu pelanggan dengan menjawab permintaan dan memberi informasi kapan pelayanan akan diberikan secara tanggap atau cepat.

Jaminan (Assurance). Kemampuan pada perusahaan untuk membangun suatu perlindungan bagi pelanggan. Jaminan dapat memiliki arti yakni karyawan terlihat menguasai keterampilan serta ilmu yang dibutuhkan agar dapat menjawab setiap pertanyaan ataupun masalah para pelanggan dan selalu memiliki sikap sopan.

Empati (Empathy). Kemampuan perusahaan dalam memberikan suatu perhatian tulus serta bersifat individual kepada pelanggan dengan upaya memahami keinginannya. (Zeithaml et al., 1990)

\section{Pelayanan Prima}

Pelayanan prima atau "excellent service" secara literal yaitu pelayanan terbaik atau sangat baik yang diberikan kepada pelanggan internal maupun eksternal perusahaan sesuai dengan ketentuan dan prosedur pelayanan instansi yang berlaku dan sudah ditentukan dengan tujuan untuk dapat memenuhi harapan serta kebutuhan dari pelanggan (Daryanto, 2014); (Rangkuti, 2017); (Zaenal Mukarom \& Muhibudin Wijaya Laksana, 2018).

Berdasarkan penelitian ini, pelayanan prima tersebut adalah suatu layanan terbaik yang diberikan Batik Air sesua dengan standar kualitas untuk memenuhi harapan dan kebutuhan penumpang agar tercipta kepuasan sehingga menimbulkan loyalitas penumpang.

\section{Loyalitas Pelanggan}

Loyalitas dapat diartikan sebagai "perilaku seseorang yang terbiasa melakukan pembelian ulang serta interaksi yang berjalan selama periode waktu tertentu (Griffin, 2005). Menurut Oliver, "meski pengaruh dari kondisi serta usaha promosi memiliki peluang untuk membuat suatu perubahan sikap, namun pelanggan tetap memiliki komitmen dan bertahan secara mendalam agar dapat berlangganan kembali atau melakukan suatu pembelian sebuah produk atau jasa terpilih secara konsisten di mendatang. Hal ini disebut loyalitas pelanggan (Sangadji, 2013).

\section{Tahapan Loyalitas Pelanggan}

Agar menjadi pelanggan loyal, pelanggan akan melalui beberapa tahapan. Proses ini harus dimengerti setiap pemasar karena pada tiap tahapnya memiliki kebutuhan khusus. Kotler dan Keller menjelaskan tiga indikator dari loyalitas pelanggan yakni; (1) Repeat Purchase, merupakan kesetiaan pada pembelian jasa; (2) Retention, merupakan ketahanan agar tidak terpengaruh negatif tentang perusahaan; (3) Referrals, secara keseluruhan mereferensikan eksistensi sebuah perusahaan (Kotler \& Keller, 2006).

\section{Pengaruh Kualitas Pelayanan Terhadap Loyalitas Pelanggan}

Dalam bidang jasa, kegiatan pelayanan adalah hal yang sangat penting. Sangat penting untuk mengatur strategi yang tepat serta efektif sehingga tujuan perusahaan dapat tercapai demi menjaga penyediaan dan tingkat konsumsi jasa tetap dapat dipertahankan dan berlangsung dengan lancar. Dengan adanya kualitas jasa yang baik, maka semua yang dirasakan pelanggan sesuai dengan yang mereka harapkan, sehingga pelanggan akan merasakan kepuasan.

Pada penelitian ini diamati variabel-variabel yang ada di dalam kualitas jasa, diantaranya; daya tanggap, empati, bukti fisik, jaminan dan keandalan. Pada dasarnya usaha untuk memuaskan pelanggan adalah suatu usaha untuk mengembangkan kualitas dari barang atau jasa perusahaan ke arah memberi kepuasan untuk kebutuhan pelanggan yang sesuai 
atau melebihi ketentuan yang diinginkan oleh pelanggan.

Definisi loyalitas pelanggan adalah "loyalitas pelanggan yaitu suatu komitmen pelanggan terhadap suatu merek, toko atau pemasok berdasarkan sifat yang sangat positif pada pembelian dalam jangka panjang" (Tjiptono, 2007).

Dari definisi tersebut, kesetiaan terhadap suatu merek diperoleh karena adanya sebuah kombinasi dari kepuasan serta keluhan. Sedangkan kepuasan pelanggan hadir dari seberapa besar kinerja suatu perusahaan untuk menimbulkan kepuasan tersebut dengan meminimalkan keluhan sehingga dapat diperoleh suatu pembelian jangka panjang yang dilakukan oleh konsumen.

Kotler \& Keller menyebutkan ada tiga indikator dari loyalitas pelanggan yakni kesetiaan kepada pembelian produk/jasa, ketahanan terhadap sebuah pengaruh negatif mengenai perusahaan, mereferensikan secara total eksistensi pada perusahaan (Kotler \& Keller, 2006).

Berdasarkan masalah penelitian, dapat digambarkan suatu kerangka teoritis mengenai kualitas pelayanan Batik Air terhadap loyalitas pelanggan kelas ekonom, sebagai berikut:

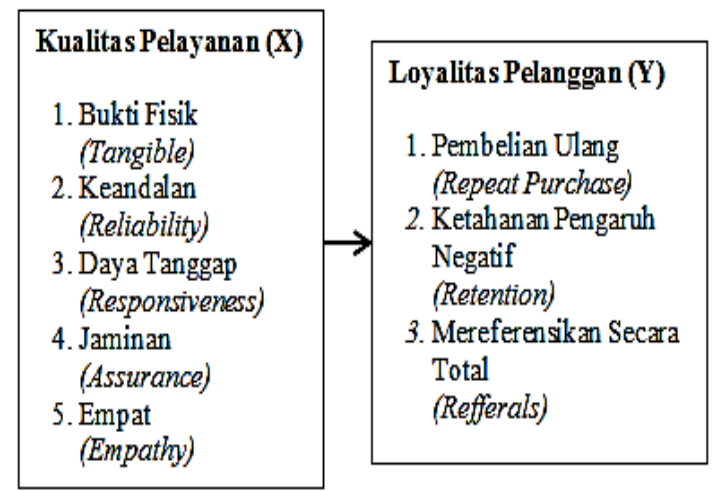

Gambar 1. Kerangka Pemikiran

Berdasarkan kerangka pemikiran tersebut, hipotesisnya sebagai berikut:

Ho: Tidak ada pengaruh antara kualitas pelayanan Batik Air terhadap loyalitas penumpang

kelas ekonomi.

$\mathrm{Ha}$ : Ada pengaruh antara kualitas pelayanan terhadap loyalitas penumpang kelas ekonomi.

\section{METODE PENELITIAN}

Peneliti menggunakan pendekatan kuantitatif dengan metode penelitian yang digunakan adalah survei dan jenis penelitian bersifat eksplanatif. Penelitian dengan pendekatan kuantitatifi adalah penelitian berupa butir-butir angka dan dianalisis menggunakan statistik. Peneliti menggunakan metode penelitian survei yang berarti proses pengukuran yang digunakan untuk mengumpulkan data dengan menggunakan kuesioner.

Jenis penelitian ini bersifat eksplanatif, yaitu pendekatan yang digunakan peneliti untuk menguji hipotesis, menggali data dari responden dan juga untuk menjelaskan hubungan dari beberapa variabel bebas dan terikat dalam penelitian yang tujuannya menjelaskan hubungan dan pengaruh melalui pengujian hipotesis" (Putra, 2012); (Sugiyono, 2013); (Supriyanto, 2010).

Populasi diartikan sebagai sekumpulan atau sekelompok objek yang akan digeneralisasikan dari sebuah hasil penelitian (Widiyanto, 2010). Populasi penelitian ini merupakan penumpang Batik Air periode tahun 2019. 
Tabel 1. Data Penumpang Tahun 2019

\begin{tabular}{|c|c|c|}
\hline No. & Bulan & Jumlah Penumpang (Dewasa) \\
\hline 1. & Januari & 880.352 \\
\hline 2. & Februari & 763.384 \\
\hline 3. & Maret & 899.086 \\
\hline 4. & April & 833.748 \\
\hline 5. & Mei & 720.696 \\
\hline 6. & Juni & 871.405 \\
\hline 7. & Juli & 984.945 \\
\hline 8. & Agustus & 914.116 \\
\hline 9. & September & 921.060 \\
\hline 10. & Oktober & 1.024 .911 \\
\hline 11. & November & 1.082 .045 \\
\hline \multirow[t]{2}{*}{12.} & Desember & 1.094 .148 \\
\hline & TOTAL & 10.989 .896 \\
\hline
\end{tabular}

Jumlah populasi penelitian ini 10.989 .896 penumpang yaitu penumpang Batik Air periode tahun 2019 (Januari-Desember). Batik Air melakukan rekapitulasi data penumpang setiap satu tahun sekali pada akhir tahun. Peneliti menggunakan data penumpang Batik Air yang telah selesai direkapitulasi satu tahun sebelumnya untuk dijadikan sebagai populasi penelitian dan untuk menghitung jumlah sampel.

Pada penelitian ini peneliti menggunakan dua data penumpang yaitu dari periode tahun 2019 dan tahun 2020. Data penumpang Batik Air periode tahun 2019 digunakan untuk menentukan populasi dan sampel. Sedangkan data penumpang Batik Air periode tahun 2020 digunakan sebagai responden yang melakukan penerbangan dari bulan Januari-Desember 2020 dan hasil data penelitian tersebut dihitung untuk melihat pengaruh kualias pelayanan terhadap loyalitas penumpang.

Sampel adalah sebagian dari anggota populasi yang akan diteliti dan dipilih menggunakan prosedur tertentu dengan ciri-ciri atau keadaan yang diharapkan dapat mewakili populasi (Martono, 2011). Dari perhitungan menggunakan rumus Slovin, didapat sampel berjumlah 99,9 dibulatkan menjadi 100 respoden.

Peneliti menggunakan teknik pengambilan sampling yaitu Non-Probability Sampling dengan jenis teknik pengambilan Purposive Samping berdasarkan kriteria yang telah ditentukan yaitu: (1) Responden merupakan penumpang laki-laki atau perempuan warga negara Indonesia; (2) penumpang Batik Air kelas ekonomi dengan periode penerbangan tahun 2020 dari Bandara Soekarno Hatta; (3) penumpang berusia 35-65 tahun; (4) menggunakan Batik Air lebih dari tiga kali penerbangan one way.

Dalam penelitian ini, peneliti menggunakan data primer yang dikumpulkan peneliti langsung dari sumber pertama, yaitu menggunakan kuesioner. Peneliti menggunakan skala likert dalam kuesioner penelitian dengan memodifikasi skor nilai mulai dari 1-4 untuk mendapatkan jawaban pasti dari butir-butir kuesioner yang telah diisi oleh responden.

Pengolahan informasi pada riset dengan pendekatan kuantitatif adalah suatu proses dalam mendapatkan ringkasan informasi dengan metode ataupun rumusan tertentu semacam editing, coding, serta tabulasi.

Peneliti menganalisis data yang diperoleh dengan teknik analisis PLS (Partial Least Square) dengan tahapan pengujian model pengukuran melalui uji validitas dan reliabilitas serta pengujian model struktural SEM (Stuctural Equation Modeling) untuk menilai signifikansi statistik dari hubungan yang dihipotesiskan (Hamidi, 2010); (Kriyantono, 2009); (Singarimbun, 2011); (Sugiyono, 2013).

Menurut (Arikunto, 2010), validitas adalah suatu ukuran yang menunjukkan tingkat 
kevalidan atau keabsahan suatu instrumen. Suatu instrumen dikatakan valid jika instrumen dapat mengukur apa yang akan diukur. Dengan demikian instrumen tersebut dapat menjaring data untuk mengungkapkan tujuan penelitian.

Menurut (Azwar, 2015), reliabilitas alat ukur digunakan untuk mengetahui sejauh mana suatu alat ukur dapat diandalkan. Kemudian dalam penelitian ini, uji reliabilitas dilakukan dengan cara test dan re-test. Hal tersebut dilakukan untuk mengetahui apakah penelitian ini telah valid dan memiliki hasil yang terus konsisten. Kaplan dan Saccuzo dalam (Siregar, 2013) menyatakan, alat ukur penelitian yang reliabilitasnya diuji dengan test dan re-test dilakukan dengan cara mencobakan alat ukur itu beberapa kali ke responden.

\section{HASIL PENELITIAN}

Sebelum instrumen digunakan sebagai alat pengumpulan data, instrumen harus diuji terlebih dahulu agar peneliti mendapatkan instrumen yang valid dan reliabel. Pengujian instrumen dalam penelitian ini meliputi uji validitas dan reliabilitas. Pengujian validitas dilakukan terhadap 30 responden. Pengambilan keputusan berdasarkan pada nilai r-hitung $>$ $r$-tabel sebesar 0,361 , untuk df $=30-2=28 ; \alpha=0,05$ maka pernyataan tersebut valid.

Berdasarkan hasil pengolahan diperoleh uji validitas sebagai berikut:

Tabel 2. Hasil Uji Validitas Variabel Kualitas Pelayanan

\begin{tabular}{|l|l|l|l|}
\hline Items & R Hitung & R Tabel & Keterangan \\
\hline$X_{1}$ & 0,725 & 0,361 & Valid \\
\hline$X_{2}$ & 0,538 & 0,361 & Valid \\
\hline$X_{3}$ & 0,579 & 0,361 & Valid \\
\hline$X_{4}$ & 0,758 & 0,361 & Valid \\
\hline$X_{5}$ & 0,681 & 0,361 & Valid \\
\hline$X_{6}$ & 0,775 & 0,361 & Valid \\
\hline$X_{7}$ & 0,550 & 0,361 & Valid \\
\hline$X_{8}$ & 0,791 & 0,361 & Valid \\
\hline$X_{9}$ & 0,803 & 0,361 & Valid \\
\hline$X_{10}$ & 0,656 & 0,361 & Valid \\
\hline$X_{11}$ & 0,651 & 0,361 & Valid \\
\hline$X_{12}$ & 0,718 & 0,361 & Valid \\
\hline$X_{13}$ & 0,646 & 0,361 & Valid \\
\hline$X_{14}$ & 0,565 & 0,361 & Valid \\
\hline$X_{15}$ & 0,627 & 0,361 & Valid \\
\hline$X_{16}$ & 0,506 & 0,361 & Valid \\
\hline$X_{17}$ & 0,764 & 0,361 & Valid \\
\hline$X_{18}$ & 0,733 & 0,361 & Valid \\
\hline$X_{19}$ & 0,732 & 0,361 & Valid \\
\hline$X_{20}$ & 0,790 & 0,361 & Valid \\
\hline$X_{21}$ & 0,773 & 0,361 & Valid \\
\hline$X_{22}$ & 0,725 & 0,361 & Valid \\
\hline$X_{23}$ & 0,797 & 0,361 & Valid \\
\hline$X_{24}$ & 0,859 & 0,361 & Valid \\
\hline$X_{25}$ & 0,635 & 0,361 & Valid \\
\hline & & & \\
\hline
\end{tabular}

Hasil uji validitas pada variabel kualitas pelayanan, diketahui dari 25 pernyataan yang diajukan terhadap 30 responden, nilai $r$-hitung berada di atas nilai $r$-tabel ( $r$-hitung $>$ r-tabel) sehingga keseluruhan pertanyaan pada variabel telah ivalid. 
Tabel 3. Hasil Uji Validitas Variabel Loyalitas Penumpang

\begin{tabular}{|l|l|l|l|}
\hline Items & R Hitung & R Tabel & Keterangan \\
\hline$Y_{1}$ & 0,723 & 0,361 & Valid \\
\hline$Y_{2}$ & 0,671 & 0,361 & Valid \\
\hline$Y_{3}$ & 0,777 & 0,361 & Valid \\
\hline$Y_{4}$ & 0,850 & 0,361 & Valid \\
\hline$Y_{5}$ & 0,715 & 0,361 & Valid \\
\hline$Y_{6}$ & 0,773 & 0,361 & Valid \\
\hline$Y_{7}$ & 0,707 & 0,361 & Valid \\
\hline$Y_{8}$ & 0,620 & 0,361 & Valid \\
\hline$Y_{9}$ & 0,707 & 0,361 & Valid \\
\hline
\end{tabular}

Hasil uji validitas pada variabel loyalitas penumpang diketahui, dari 9 pernyataan yang diajukan kepada 30 responden diperoleh nilai r-hitung di atas nilai r-tabel ( $r$-hitung $>$ r-tabel) sehingga keseluruhan pertanyaan pada variabel telah valid.

\section{Uji Reliabilitas}

Hasil uji reliabilitas terhadap semua item dalam penelitian ini menunjukkan, item penelitian dapat dikatakan reliabel (nilai koefisien reliabilitas lebih besar dari 0,60). Berikut adalah hasil uji reliabilitas dengan menggunakan program SPSS iv.25.

Tabel 4. Hasil Uji Reliabilitas Variabel Kualitas Penumpang dan Loyalitas Penumpang

\begin{tabular}{|l|c|c|c|}
\hline \multicolumn{1}{|c|}{ Variabel } & $\begin{array}{c}\text { Alpha } \\
\text { Cronbach }\end{array}$ & $\begin{array}{c}\text { Nilai } \\
\text { Kritis }\end{array}$ & Keterangan \\
\hline Kualitas Pelayanan (X) & 0,954 & 0,60 & Reliabel \\
\hline Loyalitas Penumpang (Y) & 0,886 & 0,60 & Reliabel \\
\hline
\end{tabular}

Berdasarkan hasil uji reliabilitas nilai dari Alpha Cronbach untuk hasil reliabilitas kuesioner berada di atas batas 0,60 artinya kuesioner ini mampu menjawab pertanyaan yang mewakili keadaan sebenarnya dan bila pengukuran tersebut diulang maka jawaban responden akan tetap konsisten.

Tabel 5. Kriteria Responden Berdasarkan Jenis Kelamin

\begin{tabular}{|c|c|c|c|c|c|}
\hline \multicolumn{7}{|c|}{ Jenis Kelamin } \\
\hline \multirow{2}{|c|}{} & Frequency & Percent & $\begin{array}{c}\text { Valid } \\
\text { Percent }\end{array}$ & $\begin{array}{c}\text { Cumula } \\
\text { tive } \\
\text { Percent }\end{array}$ \\
\hline \multirow{3}{*}{ Valid } & Laki-laki & 36 & 36.0 & 36.0 & 36.0 \\
\cline { 2 - 6 } & Perempuan & 64 & 64.0 & 64.0 & 100.0 \\
\cline { 2 - 6 } & Total & 100 & 100.0 & 100.0 & \\
\hline
\end{tabular}

Berdasarkan Tabel 5, diketahui mayoritas responden berjenis kelamin perempuan yaitu sebanyak 64 responden (64\%).

Tabel 6. Responden Berdasarkan Usia

\begin{tabular}{|c|c|c|c|c|c|}
\hline \multicolumn{5}{|c|}{ Pekerjaan } \\
\hline \multirow{7}{*}{} & Frequency & Percent & $\begin{array}{c}\text { Valid } \\
\text { Percent }\end{array}$ & $\begin{array}{c}\text { Cumulative } \\
\text { Percent }\end{array}$ \\
\cline { 2 - 6 } & $\begin{array}{c}\text { Pegawai } \\
\text { Swasta }\end{array}$ & 83 & 83.0 & 83.0 & 83.0 \\
\cline { 2 - 6 } Valid & $\begin{array}{c}\text { Pegawai } \\
\text { BUMN }\end{array}$ & 10 & 10.0 & 10.0 & 93.0 \\
\cline { 2 - 6 } & $\begin{array}{c}\text { Ibu Rumah } \\
\text { Tangga }\end{array}$ & 5 & 5.0 & 5.0 & 98.0 \\
\cline { 2 - 6 } & Freelancer & 2 & 2.0 & 2.0 & 100.0 \\
\cline { 2 - 6 } & Total & 100 & 100.0 & 100.0 & \\
\hline
\end{tabular}


Berdasarkan Tabel 6 diketahui mayoritas responden merupakan pegawai swasta, yaitu sebanyak 83 orang (83\%).

Tabel 7. Kriteria Responden Berdasarkan Frekuensi Penerbangan

\begin{tabular}{|c|c|c|c|c|c|}
\hline \multicolumn{6}{|c|}{ Frekuensi } \\
\hline \multirow{2}{*}{} & Frequency & Percent & $\begin{array}{c}\text { Valid } \\
\text { Percent }\end{array}$ & $\begin{array}{c}\text { Cumulative } \\
\text { Percent }\end{array}$ \\
\hline \multirow{3}{*}{ Valid } & $\begin{array}{c}3-4 \\
\text { kali }\end{array}$ & 89 & 89.0 & 89.0 & 89.0 \\
\cline { 2 - 6 } & $\begin{array}{c}\geq 5 \\
\text { kali }\end{array}$ & 11 & 11.0 & 11.0 & 100.0 \\
\cline { 2 - 6 } & Total & 100 & 100.0 & 100.0 & \\
\hline
\end{tabular}

Berdasarkan Tabel 7, diketahui mayoritas responden memiliki frekuensi penerbangan 3-4 kali selama tahun 2020 yaitu sebanyak 89 responden (89\%).

Tabel 8. Responden Berdasarkan Bandara Keberangkatan/Kedatangan

\begin{tabular}{|c|c|c|c|c|c|}
\hline \multicolumn{6}{|c|}{ Bandara Keberangkatan/Kedatangan } \\
\hline \multicolumn{2}{|c|}{} & Frequency & Percent & $\begin{array}{c}\text { Valid } \\
\text { Percent }\end{array}$ & $\begin{array}{c}\text { Cumulative } \\
\text { Percent }\end{array}$ \\
\hline Valid & $\begin{array}{c}\text { Bandara } \\
\text { Soekarno- } \\
\text { Hatta }\end{array}$ & 100 & 100.0 & 100.0 & 100.0 \\
\hline
\end{tabular}

Berdasarkan Tabel 8 diketahui seluruh responden memiliki rute keberangkatan/kedatangan dari Bandara Soekarno-Hatta sebanyak 100 responden (100\%).

\section{Analisis Deskriptif Variabel $X$}

Variabel kualitas pelayanan terdiri dari 25 pernyataan yang digunakan untuk mengukur variabel kualitas pelayanan yang dalam pengambilan datanya menggunakan kuesioner. Indikator tersebut dituangkan dalam item pertanyaan untuk setiap indikator.

\begin{tabular}{|c|c|c|c|c|}
\hline \multirow{2}{*}{ Item } & \multicolumn{4}{|c|}{ Frekuensi } \\
\cline { 2 - 5 } & STS & TS & S & SS \\
\hline X1 & 0 & 0 & 16 & 84 \\
\hline X3 & 0 & 0 & 40 & 60 \\
\hline X4 & 0 & 0 & 31 & 68 \\
\hline X5 & 0 & 0 & 32 & 78 \\
\hline X6 & 0 & 0 & 33 & 68 \\
\hline X7 & 0 & 0 & 27 & 73 \\
\hline X8 & 0 & 0 & 32 & 68 \\
\hline X9 & 0 & 0 & 24 & 76 \\
\hline X10 & 0 & 1 & 30 & 69 \\
\hline X11 & 0 & 1 & 30 & 69 \\
\hline X12 & 0 & 0 & 23 & 77 \\
\hline X13 & 0 & 1 & 33 & 66 \\
\hline X14 & 0 & 0 & 26 & 74 \\
\hline X15 & 0 & 0 & 43 & 57 \\
\hline X16 & 0 & 0 & 24 & 76 \\
\hline X17 & 0 & 0 & 33 & 67 \\
\hline X18 & 0 & 1 & 30 & 69 \\
\hline X19 & 0 & 1 & 37 & 62 \\
\hline
\end{tabular}




\begin{tabular}{|c|c|c|c|c|}
\hline $\mathrm{X} 20$ & 0 & 0 & 32 & 68 \\
\hline $\mathrm{X} 21$ & 0 & 0 & 24 & 76 \\
\hline $\mathrm{X} 22$ & 0 & 0 & 32 & 68 \\
\hline $\mathrm{X} 23$ & 0 & 0 & 30 & 70 \\
\hline $\mathrm{X} 24$ & 0 & 0 & 29 & 71 \\
\hline $\mathrm{X} 25$ & 0 & 0 & 33 & 67 \\
\hline
\end{tabular}

Untuk mengetahui gambaran mengenai variabel penelitian dilakukan dengan cara sebagai berikut:

Menentukan data terbesar dan data terkecil

Data terbesar $=4 \times 25 \times 100=10000$

Data terkecil $=1 \times 25 \times 100=2500$

Menentukan jangkauan (R)

$\mathrm{R}=$ data terbesar-data terkecil

$R=10000-2500=7500$

Membuat panjang intervalikelas (int)

$$
\text { Int }=\frac{7500}{5}=1500
$$

Membuat tabel rentang klasifikasi

Untuk memudahkan penilaian jawaban responden, dibuat kriteria penilaian berdasarkan skor rata-rata sebagai berikut:

Tabel 9. Rentang Klasifikasi Variabel X

\begin{tabular}{|l|l|}
\hline Lebar Interval & Kategori \\
\hline $2500-4000$ & Sangat iKurang \\
\hline $4000-5500$ & Tidak iBaik \\
\hline $5500-7000$ & Cukup iBaik \\
\hline $7000-8500$ & Baik \\
\hline $8500-10000$ & Sangat iBaik \\
\hline
\end{tabular}

$$
\begin{aligned}
& \% \text { skor tanggapan responden }=\frac{9241}{(4 \times 25 \times 100)} \times 100 \% \\
& \% \text { skor tanggapan responden }=\frac{9241}{10000} \times 100 \%=92,4 \%
\end{aligned}
$$

Gambar 1. Garis Kontinum Variabel X

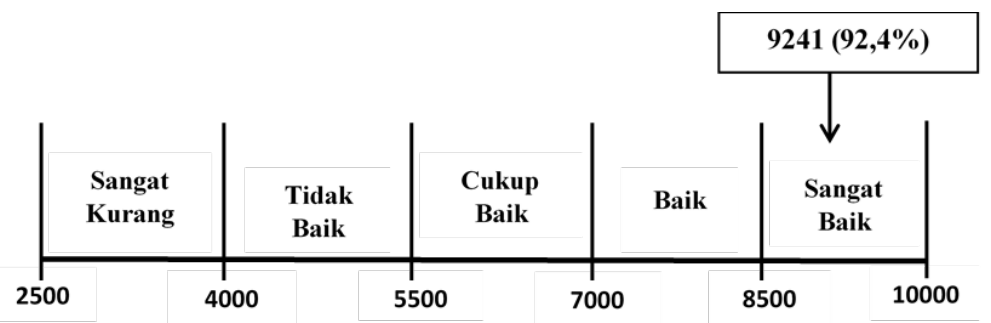

Berdasarkan Gambar 1, tanggapan responden atas variabel kualitas pelayanan menghasilkan skor 9241 (92,4\%) yang berada dalam kategori "Sangat Baik". Artinya secara Pengaruh Kualitas Pelayananan terhadap Loyalitas Penumpang Maskapai Penerbangan Batik (Grace N Valencia) 
keseluruhan penerapan kualitas pelayanan Batik Air bagi penumpangnya sudah sangat baik.

\begin{tabular}{|c|c|c|c|c|}
\hline \multirow{2}{*}{ Items } & \multicolumn{4}{|c|}{ Frekuensi } \\
\cline { 2 - 5 } & STS & TS & S & SS \\
\hline Y1 & 0 & 0 & 32 & 68 \\
\hline Y2 & 0 & 0 & 21 & 79 \\
\hline Y3 & 0 & 0 & 32 & 68 \\
\hline Y4 & 0 & 0 & 27 & 73 \\
\hline Y5 & 0 & 0 & 24 & 76 \\
\hline Y6 & 0 & 0 & 23 & 77 \\
\hline Y7 & 0 & 0 & 22 & 78 \\
\hline Y8 & 0 & 0 & 21 & 79 \\
\hline Y9 & 0 & 0 & 21 & 79 \\
\hline
\end{tabular}

Untuk mengetahui gambaran tentang variabel penelitian, dilakukan dengan:

Menentukan data terbesar dan data terkecil

Data terbesar $=4 \times 9 \times 100=3600$

Data terkecil $=1 \times 9 \times 100=900$

Menentukan jangakuan ( $R$ )

$\mathrm{R}=$ data terbesar-data terkecil

$R=3600-900=2700$

Membuat panjang interval kelas (int)

$$
\text { Int }=\frac{2700}{5}=540
$$

Membuat tabel rentang klasifikasi

Untuk memudahkan penilaian dari jawaban responden, dibuat kriteria penilaian berdasarkan skor rata-rata sebagai iberikut:

Tabel 10. Rentang Klasifikasi Variabel Y

\begin{tabular}{|l|l|}
\hline Lebar ilnterval & Kategori \\
\hline $900-1440$ & Sangat iKurang \\
\hline $1440-1980$ & Tidak iBaik \\
\hline $1980-2520$ & Cukup iBaik \\
\hline $2520-3060$ & Baik \\
\hline $3060-3600$ & Sangat iBaik \\
\hline
\end{tabular}

$\%$ skor tanggapan responden $=\frac{3377}{(4 \times 9 \times 100)} \times 100 \%$

$\%$ skor tanggapan responden $=\frac{3377}{3600} \times 100 \%=93,8 \%$

Gambar 2. Garis Kontinum Variabel Y

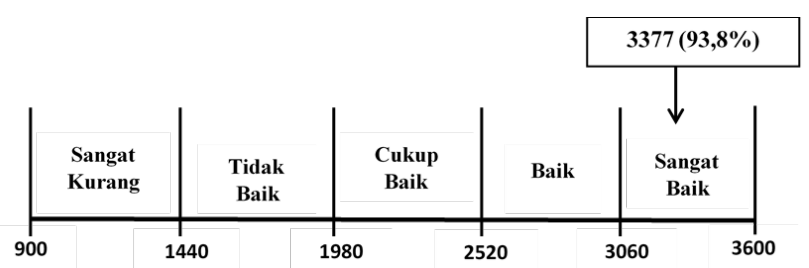


Berdasarkan Gambar 2, dapat disimpulkan tanggapan responden tentang variabel loyalitas penumpang menghasilkan skor sebesar 3377 (93,8\%) yang berada dalam kategori "Sangat Baik". Artinya secara keseluruhan loyalitas penumpang Batik Air sudah sangat baik.

\section{Analisis Regresi Linear Sederhana}

Analisis regresi linear sederhana dalam penelitian ini digunakan untuk mengetahui pengaruh kualitas pelayanan Batik Air terhadap loyalitas penumpang kelas ekonomi. Dapat dilihat pada Tabel 11, hasil uji analisis regresi linear sederhana, sebagai berikut:

Tabel 11. Hasil Analisis Regresi Linier Sederhana

\begin{tabular}{|c|c|c|c|c|c|c|}
\hline \multicolumn{7}{|c|}{ ANOVA $^{a}$} \\
\hline \multicolumn{2}{|c|}{ Model } & $\begin{array}{l}\text { Sum of } \\
\text { Squares }\end{array}$ & df & $\begin{array}{l}\text { Mean } \\
\text { Square }\end{array}$ & F & Sig. \\
\hline 1 & Regression & 263.131 & 1 & 263.131 & 74.404 & $.000^{\mathrm{b}}$ \\
\hline & Residual & 346.579 & 98 & 3.537 & & \\
\hline & Total & 609.710 & 99 & & & \\
\hline
\end{tabular}

Berdasarkan Tabel 11, didapatkan hasil nilai $\mathrm{F}$ hitung $=74.404$ dengan tingkat signifikasi $0,000<0,05$, maka model regresi dapat dipakai untuk memprediksi variabel partisipasi atau dengan kata lain ada pengaruh variabel Kualitas Pelayanan $(X)$ terhadap variabel Loyalitas Penumpang $(\mathrm{Y})$.

\section{Analisis Koefisien Determinasi}

Untuk melihat seberapa besar tingkat pengaruh variabel independen terhadap variabel dependen dan pengaruh variabel lain terhadap variabel dependen digunakan koefisien determinasi (Kd). Untuk mencari koefisien determinasi maka $r 2$ dikali dengan $100 \%$. Diperoleh hasil analisis koefisien determinasi: (1) Dependent Variable: loyalitas penumpang; (2) predictors: (Constant), kualitas pelayanan.

Hasil analisis koefisien determinasi sebagai berikut:

Tabel 12. Hasil Analisis Koefisien Determinasi

\begin{tabular}{|l|c|c|c|c|}
\hline \multicolumn{5}{|c|}{ Model Summary } \\
\hline & & & Adjusted & $\begin{array}{c}\text { Std. } \\
\text { Error of } \\
\text { the }\end{array}$ \\
Model & $\mathrm{R}$ & Square & Square & Estimate \\
\hline 1 & $.657^{\mathrm{a}}$ & 0.432 & 0.426 & 1.881 \\
\hline
\end{tabular}

Berdasarkan Tabel 12, hasil nilai korelasi (R) adalah sebesar 0,657 $(65,7 \%)$. Dari hasil tersebut diperoleh koefesien determinasi ( $R$ Square) 0,432 yang berarti pengaruh variabel bebas (Loyalitas Penumpang) terhadap variabel terikat (Kualitas Pelayanan) adalah $43,2 \%$ dan sisanya $56,8 \%$ dipengaruhi variabel lainnya.

\section{Uji $t$}

Uji parsial dilakukan untuk melihat signifikansi pengaruh masing-masing variabel dalam menerangkan variasi variabel dependen. Pengujian hipotesis dilakukan dengan menentukan nilai kritis dengan level of significant $\alpha=5 \%(\alpha=0,05)$ dengan derajat kebebasan atau $\mathrm{dk}=\mathrm{n}$ $k=100-2=98$, maka $t_{\text {tabel }}$ adalah 1,985.

Berikut tabel hasil uji-t: 
Tabel 13. Hasil Analisis Uji t

\begin{tabular}{|c|c|c|c|c|c|c|}
\hline \multicolumn{7}{|c|}{ Coefficients $^{\mathrm{a}}$} \\
\hline \multirow{2}{*}{\multicolumn{2}{|c|}{ Model }} & \multicolumn{2}{|c|}{$\begin{array}{l}\text { Unstandardized } \\
\text { Coefficients }\end{array}$} & \multirow{2}{*}{$\begin{array}{c}\begin{array}{c}\text { Standardized } \\
\text { Coefficients }\end{array} \\
\text { Beta }\end{array}$} & \multirow[b]{2}{*}{$\mathrm{t}$} & \multirow{3}{*}{$\begin{array}{l}\text { Sig. } \\
0.049\end{array}$} \\
\hline & & $\mathrm{B}$ & $\begin{array}{l}\text { Std. } \\
\text { Error }\end{array}$ & & & \\
\hline \multirow[t]{2}{*}{1} & (Constant) & 6.339 & 3.186 & & 1.990 & \\
\hline & $\begin{array}{l}\text { KUALITAS } \\
\text { PELAYANAN }\end{array}$ & 0.297 & 0.034 & 0.657 & 8.626 & 0.000 \\
\hline
\end{tabular}

Berdasarkan Tabel 13, didapat hasil nilai Constant (a) sebesar 6,339, sedangkan nilai Kualiatas Pelayanan (b/koefesien regresi) sebesar 0,297, sehingga persamaan regresinya:

$$
\begin{aligned}
& Y=a+b X \\
& Y=6,339+0,297 X
\end{aligned}
$$

Persamaan tersebut dapat diterjemahkan: Konstanta sebesar 6,339 mengandung arti, nilai konsisten variabel Loyalitas Penumpang sebesar 6,339. Koefisien regresi $X$ sebesar 0,297 menyatakan, setiap penambahan $1 \%$ nilai kualitas pelayanan, maka nilai loyalitas penumpang bertambah sebesar 0,297 . Koefesien regresi tersebut bernilai positif, sehingga arah pengaruh variabel $\mathrm{X}$ terhadap $\mathrm{Y}$ adalah positif.

Gambar 3. Kurva Pengujian Hipotesis
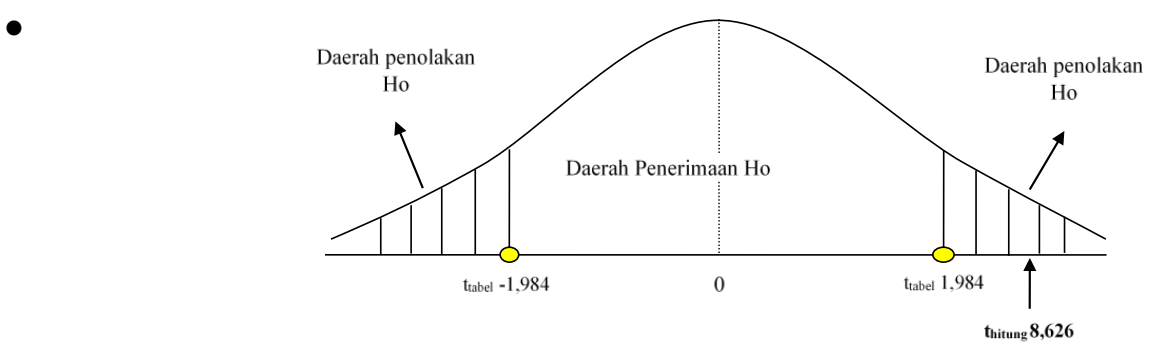

Berdasarkan nilai signifikansi dari Tabel 13, diperoleh nilai signifikansi sebesar $0,000<$ 0,05 , sehingga dapat disimpulkan variabel Kualitas Pelayanan $(X)$ berpengaruh terhadap variabel Loyalitas Penumpang (Y). Berdasarkan nilai t diketahui nilai $t_{\text {hitung }}$ sebesar 8,626 $>t_{\text {tabel }}$ 1,984 , sehingga variabel Kualitas Pelayanan $(X)$ berpengaruh terhadap variabel Loyalitas Penumpang $(\mathrm{Y})$.

Berdasarkan analisis deskriptif pada variabel Kualitas Pelayanan secara keseluruhan dinilai sangat baik dengan skor 9241 (92,4\%). Pernyataan dengan skor tertinggi adalah "Armada pesawat yang digunakan Batik Air memiliki keamanan yang baik" sebesar 384, artinya Batik Air sudah sangat baik dalam memberikan keamanan bagi para penumpangnya. Sedangkan pernyataan dengan skor terendah adalah "Penumpang merasa nyaman selama penerbangan" sebesar 357, artinya banyak penumpang Batik Air kurang merasa nyaman dalam maskapai Batik Air.

\section{Loyalitas Penumpang Batik Air}

Berdasarkan analisis deskriptif variabel loyalitas penumpang secara keseluruhan dinilai sangat baik dengan skor 3377 (93,8\%). Pernyataan dengan skor tertinggi adalah "Penumpang bersedia membeli kembali tiket Batik Air pada saat low season", "Penumpang bersedia memberikan rekomendasi mengenai pelayanan penuh Batik Air sebaik mungkin kepada orang lain" dan "Penumpang bersedia menyampaikan hal positif mengenai pelayanan Batik Air kepada orang lain" sebesar 379, artinya penumpang Batik Air bersedia menggunakan kembali layanan Batik Air pada low season serta penumpang juga bersedia mempengaruhi orang lain 
mengenai fasilitas dan hal positif Batik Air.

Sedangkan pernyataan dengan skor terendah adalah "Penumpang bersedia membeli kembali tiket Batik Air saat high season" dan "Penumpang bersedia melakukan pembelian pelayanan tambahan (additional service) jika membutuhkan seperti wheel chair, inflight meal, merchandise" sebesar 368, artinya penumpang Batik Air kurang bersedia menggunakan layanan Batik Air saat high season serta kurang bersedia membeli pelayanan tambahan yang disediakan Batik Air.

Berdasarkan hasil uji hipotesis menghasilkan nilai t-hitung sebesar 8,626 >1,984 artinya Kualitas Pelayanan Batik Air berpengaruh terhadap loyalitas penumpang Batik Air. Hasil temuan di lapangan terdapat responden Batik Air yang kurang nyaman dalam menggunakan layanan. Staf Batik Air seharusnya dapat menjaga kenyamanan penumpang dengan pelayanan yang diberikan. Selain itu dari aspek loyalitas penumpang ditemukan data kurangnya ketersediaan penumpang melakukan perjalanan menggunakan layanan Batik Air saat High Season dan kurangnya ketersediaan membeli pelayanan tambahan yang disediakan. Dalam hal ini penumpang kurang bersedia membayar dengan harga yang lebih tinggi.

Staf Batik Air seharusnya menjalankan pelayanannya terhadap penumpang untuk mendapatkan tingkat loyalitas. Loyalitas penumpang akan timbul bila pelayanan yang tersedia di Batik Air dapat memenuhi tingkat kenyamanan yang dibutuhkan penumpang.

Untuk mendapatkan loyalitas penumpang maka tingkat kualitas pelayanan Batik Air harus lebih baik, yakni dengan menambah tingkat kenyamanan para penumpang serta memberikan pelayanan yang sepadan dengan harga yang dikeluarkan oleh penumpang. Kualitas pelayanan yang baik dapat membawa dampak positif pada perusahaan. Hal ini dapat membuat penumpang memiliki loyalitas terhadap Batik Air serta memberikan keuntungan berupa tingkat kualitas pelayanan yang lebih baik.

\section{KESIMPULAN}

Kualitas pelayanan Batik Air sudah sangat baik. Adapun sisi kekurangan dalam pelayanan Batik Air yakni pada tingkat kenyamanan. Responden merasa, tingkat kenyamanan masih kurang sehingga hal tersebut dapat mempengaruhi terbentuknya kualitas pelayanan yang diharapkan penumpang.

Loyalitas penumpang Batik Air secara keseluruhan sudah sangat baik. Adapun sisi kekurangan pada variabel loyalitas penumpang adalah penumpang kurang bersedia membeli tiket Batik Air pada high season karena pada musim tersebut terjadi kenaikan harga tiket, dan penumpang kurang berminat melakukan pembelian pelayanan tambahan seperti wheel chair, inflight meal dan merchandise, karena penumpang harus mengeluarkan tarif ekstra jika ingin menggunakan pelayanan tambahan tersebut.

Hasil pengujian hipotesis menunjukkan, kualitas pelayanan Batik Air berpengaruh cukup kuat terhadap loyalitas penumpang. Besarnya pengaruh kualitas pelayanan terhadap loyalitas penumpang, sebesar $43,2 \%$ dan sisanya $56,8 \%$ dipengaruhi oleh variabel lainnya. Dalam hal yang sama, untuk meningkatkan loyalitas penumpang dalam pembelian ulang (repeat purchase), juga dapat memberikan variasi lainnya pada additional service, seperti sajian makanan dengan tema khusus atau merchandise khusus untuk teman/saudara/pasangan yang berulang tahun. Hal ini diharapkan mampu menambah keinginan penumpang untuk dapat melakukan pembelian kembali.

\section{DAFTAR IPUSTAKA}

Ardianto, E. (2008). Public relations praktis. Bandung: Widya Padjadjaran. Danandjaja. (2011). Peranan humas dalam perusahaan. Graha Ilmu. 
Daryanto, I. S. (2014). Konsumen dan Pelayanan Prima. Cetakan I. Yogyakarta: Gava Media. Frida, K. (2002). Dasar-dasar humas. Jakarta: PT Gahalia Indonesia.

Griffin, J. (2005). Customer loyalty: menumb \& mempertahankan kesetiaan pelanggan. Hamidi. (2010). Metode Penelitian Kualitatif. UMM Press.

Kotler, P., \& Keller, K. L. (2006). Marketing Management 12e. France: Edition Pearson Education.

Kriyantono, R. (2009). Teknis Praktis Riset Komunikasi. Predana Media Group.

Martono, N. (2011). Metode Penelitian Kuantitatif: Analisis isi dan analisis data sekunder. Jakarta PT Raya Grafindo Persada.

Moenir. (2010). Manajemen Pelayanan Umum di Indonesia. Bumi Aksara.

Putra, N. (2012). Metode Penelitian Kualitatif Pendidikan. Rajagrafindo Persada.

Rangkuti, F. (2017). Customer care excellence: meningkatkan kinerja perusahaan melalui pelayanan prima plus analisis kasus jasa raharja. Gramedia Pustaka Utama.

Ruslan, R. (2005). Manajemen Public Relations \& Media Komunikasi Konsep dan Aplikasi. Rajawali Pers.

Sangadji, E.M. dan S. (2013). Perilaku Konsumen: Pendekatan Praktis Disertai:Himpunan Jurnal Penelitian. Penerbit Andi.

Singarimbun. (2011). Metode Penelitian Survai.

Soemirat, S. (2010). Dasar-Dasar Public Relations. Rosdakarya.

Sugiyono. (2013). Metode Penelitian Pendidikan Pendekatan Kuantitatif, Kualitatif dan R\&D. Bandung: Alfabeta.

Supriyanto, A. S. (2010). Metodelogi Riset Manajemen Sumber Daya Manusia. UIN-maliki Press.

Tjiptono. (2007). Strategi Pemasaran Edisi 2. Yogyakarta: Penerbit Andi.

Widiyanto, J. (2010). SPSS for Windows Untuk Analisis Data Statistik dan Penelitian. Surakarta: BP-FKIP UMS.

Yadin, D. dan J. (2004). Public Relations. Erlangga.

Zaenal Mukarom, Z., \& Muhibudin Wijaya Laksana, M. (2018). Manajemen Pelayanan Publik. Pustaka Setia.

Zeithaml, V. A., Parasuraman, A., Berry, L. L., \& Berry, L. L. (1990). Delivering quality service: Balancing customer perceptions and expectations. Simon and Schuster. 